\title{
EXPLORATION OF LAMPUNG TRADITIONAL MUSIC IN EFFORTS TO PRESERVE CULTURE BY KULIT TIPIS COMMUNITY IN BANDAR LAMPUNG
}

\author{
Birgita Iyona Yulita \\ Fakultas Bahasa dan Seni, Universitas Negeri Semarang \\ Bagus Susetyo $^{\bowtie}$ \\ Fakultas Bahasa dan Seni, Universitas Negeri Semarang \\ Irfanda Rizki Harmono Sejati \\ Fakultas Bahasa dan Seni, Universitas Negeri Semarang
}

\begin{tabular}{l} 
Article Info \\
\hline Submitted : April, 2021 \\
Revised : May, 2021 \\
Accepted : May, 2021
\end{tabular}

Keywords: Exploration, Traditional Music, Conservation
Abstract

Traditional music is one of the elements of culture keeping the continuity, dynamics, cultural identity and also becoming a vehicle for transmitting the cultural values inherited from generation to generation. This study aims to identify and describe the exploration of traditional music Lampung as an effort to preserve music culture by the Kulit Tipis community in Bandar Lampung. This research was conducted using qualitative methods. Data collection techniques used literature study, observation, interviews, and documentation studies. The results showed that there were efforts to preserve Lampung traditional music by Kulit Tipis community in Bandar Lampung, namely: (1) Collaborating traditional Lampung musical instruments with modern musical instruments or traditional musical instruments from other regions. (2) Making musical compositions from Lampung folk songs or modern pop songs today. (3) Performing musical exploration performances in various festivals, regular bands, and competitions in Lampung or outside the Lampung area. (4) Creating and uploading their video recordings of musical composition performances from the Kulit Tipis community through social media, such as YouTube. 


\section{INTRODUCTIONS}

Culture is a national identity that must be protected and respected. Culture cannot be separated from people's lives because all aspects of people's lives can be said to be a form of culture, for example, human ideas or thoughts, human activities, or humangenerated works. Likewise, as stated by Koentjaraningrat (1984) that culture is a whole system of ideas, actions and human works in the context of community life which is made into the human property by learning. This is a matter of pride as well as a challenge for all Indonesian people to be able to maintain the local culture in the midst of many foreign cultural influences that can damage local culture.

Indonesia is rich with various arts and culture, so it is rightly for the Indonesian nation and people to preserve and maintain the variety of arts and culture that exist in Indonesia. Preserving Indonesian culture also means preserving the arts which include traditional music in it. The existence of traditional music in its development also really needs to be preserved by the community itself and avoid extinction.

Traditional music is one of the elements of culture, art does not only touch the elements of itself, but also aspects of human life. The problem of art is inseparable from the problem of all human habits or culture in their lives. Therefore, art is inherent in the characteristics of culture, namely that art is a common property that has a set of values, ideas, and a basis for behaviour (Rohidi, 2000)

Although traditional arts have such significance, traditional music is now being forgotten. Along with the development of the times, causing changes in the lifestyle of more modern society. As a result, people prefer a new culture that may be considered more practical than the local culture. This can be seen by the frequent occurrence of Indonesian people, especially the young generation nowadays who are starting to follow foreign cultures such as they prefer listening to and playing modern popular music from foreign cultures (pop, rock, jazz, kpop, etc.) and so on) compared to traditional Indonesian music.
The decreasing interest and enthusiasm of the public to watch, introduce or learn traditional arts. In line with the progress of a society, the greater the influence from outside that is received by the community. The impact of the domination of foreign culture on society will slowly erode regional culture and the love of the community, especially teenagers, for Indonesian arts. This needs attention by the government and the community about the importance of preserving regional culture.

Lampung is the gateway to Sumatra Island, so it is inhabited by various immigrant tribes who more or less bring their native arts. Therefore, traditional Lampung music as we know it today was formed through a process of acculturation and has met with traditional music from other regions.

Traditional music from ethnic groups who live in Lampung Province is basically a regional cultural heritage that cannot be separated from Indonesian culture in general. Traditional musical instruments are music that is taught or passed down orally, not written and is always changing (Supanggah, 1995).

In Lampung, many of the traditional musical instruments are unique and beautiful. Unfortunately, the uniqueness and beauty of traditional music in Lampung is slowly becoming extinct. The existence of traditional music is almost invisible in the Lampung area, only a small number of areas in Lampung are still familiar with the traditional musical instrument of Lampung itself. The large number of immigrants who live in the city of Bandar Lampung is one of the factors of the erosion of Lampung culture. Lampung Province has a pluralistic culture, this is indicated by the smaller number of native Lampung residents, namely 39,236 people, while the number of immigrants is 739,687 people (Roguska, 2015). The immigrants who live in Lampung are around $84 \%$. The largest ethnic groups are Javanese at $30 \%$, Banten/Sunda at $20 \%$, Minangkabau at $10 \%$ and Sumendo at $12 \%$. Other ethnic groups that are quite large in number are Balinese, Batak, Bengkulu, Bugis, Chinese, Ambonese, and Riau. Thus, Lampung culture, especially traditional musical instruments, is increasingly fading from the Lampung area itself. 
In addition, nowadays the existence of Lampung Traditional Music is less well known by the wider community because indeed this music is only performed at certain events, especially traditional events so that it seems that this music is formal and less attractive for the younger generation. This problem arises because of the modernization era where young people prefer modern music from the West and so on. In addition, young people also do not know about their local musical instruments because local music is less popular than modern music.

According to cultural researcher ECSD (Edelweiss Center for Sustainable Development) Ricky Irawan in the discussion "Lampungnese Music in Motion" stated that there were three main factors that caused the extinction of Lampung traditional music. The first factor is the loss of cultural practices in which the music is in it. The second factor, there is a change in the economic culture of Lampung cultural music because many musicians cannot afford their life from what they have created from traditional music, especially Lampung traditional music. Furthermore, the last one is the failure of the old generation to regenerate to orbit the younger generation as the successor for traditional Lampung music, so that the younger generation's lack of interest in enjoying and learning Lampung traditional music, will result in the development of traditional music preservation going in place.

The preservation of Lampung culture in Bandar Lampung City is still very minimal, especially Lampung folk music or songs, it needs special attention so that the cultural values of the Lampung people can always be maintained and sustainable so that future generations will still recognize and apply the positive values contained in Lampung culture. The lack of participation and appreciation from the younger generation also greatly impacting the sustainability of Lampung traditional music in the future. Most of the teenagers or the younger generation in Lampung often consider Lampung traditional music as ancient music that is very outdated for them to listen to or play.

This research needs to be done because there is no research on the exploration of traditional Lampung music as an effort to preserve musical culture. Therefore, the author is interested in conducting research on the exploration of traditional music related to preservation efforts in Lampung.

\section{METHODS}

The research method used in this research is a qualitative research method with descriptive exposure. The qualitative research approach means that the interpretation of the content is made and compiled in a systematic or comprehensive and systematic way. Qualitative research is a research procedure that produces descriptive data in the form of written or spoken words from people and observable behaviour (Bogdan and Taylor cited by Moleong (2011, p.4). By using this descriptive qualitative research method, the researcher collects data from observations and interviews with sources in question directly related to art Lampung tradition. Then the data is analyzed so as to obtain an overview of the issues and can be deduced.

The target of this research is members of the Kulit tipis community. There are four data retrieval or data collection technique namely literature study, observation, interviews and documentation study. The documentation study method is a data collection technique by reviewing various books, literature, notes, and various reports related to the problem to be solved. This observation method is used to record something with the help of instruments and recording in real situation conditions to increase and complete the data from the interviews. The interview used was formatted, which was conducted by way of direct question and answer with several respondents who were considered to know and understand the problem being studied in a structured manner with an instrument guide list of questions to be asked, with the aim of obtaining information about the exploration of traditional Lampung music by the Kulit Tipis community in Bandar Lampung.

The data validity technique uses triangulation of sources, methods, and theories. The data that has been collected is then analyzed in three steps, namely data reduction, data presentation, and concluding.

\section{RESULTS AND DISCUSSION}

\section{Kulit Tipis Community}

Kulit Tipis is the name of a traditionalmodern music community that grows and develops in the city of Bandar Lampung. The name Kulit Tipis itself was inspired by the percussion instrument Rebana. Even though the tambourine has a Kulit Tipis, the sound it produces is loud, as is the case with the Kulit 
Tipis community, which is the philosophy of staying thin even though it is thick (in many ways, including knowledge and experience). The Kulit tipis Community was formed on September 5 2018, has 16 active members consisting of students from the University of Lampung, chaired by Ryansyah Putra.

This community basecamp located at Jalan Mata Intan, no. 8, Tanjung Karang Barat, Bandar Lampung, Lampung. There are regular exercises carried out by this community, namely every Monday night and Wednesday night each member gathers to practice and exchange ideas about the millennial Lampung regional musical arts that they are engaged in.

\section{Exploration of Lampung Traditional Music by the Kulit tipis Community in Bandar Lampung}

As the times progressed, traditional music became rare, especially traditional music in Lampung Province. With the above phenomenon, it is necessary to explore as a form of creativity and innovation in developing Indonesian traditional music so that traditional music, especially Lampung, can continue to exist both in Lampung Province itself and throughout Indonesia. Therefore, this Kulit Tipis community in Bandar Lampung creates musical works by exploring them into new and interesting musical performances. The exploration includes:

\subsection{Collaboration of Traditional Musical Instruments with Modern Musical Instruments}

In the routine training activities carried out by the Kulit tipis community, there is an exploration process through jamming. This exploration is carried out by collaborating traditional musical instruments, both traditional Lampung musical instruments themselves and traditional musical instruments from other regions with modern musical instruments.

According to Ryansyah, the chairman of the Kulit Tipis community, the group combine or play the traditional music instrument with other musical instruments will produce a unique musical composition. This fits the modern traditional music genre so that it is easily accepted by the wider community.

Bringing modern songs by adding ethnic musical instruments to the musical composition or vice versa by bringing folk or traditional songs by combining ethnic musical instruments with modern musical instruments is the hallmark of the Kulit Tipis community. Here are some musical instruments from Lampung that are often used such as Gamolan Pekhing, Gambus Lunik, Serdam, Talo Balak instruments (kulintang, talo, gung, gujih, canang, kendang dok-dok), and Kerenceng/Terbangan.

Other ethnic musical instruments that are often played by the Kulit tipis community are Bamboo Flute from West Java, Bansi from West Sumatra (Minangkabau), Sampelong from West Sumatra (Minangkabau), Jimbe from Africa, and the accordion from South Sumatra. Often the community brings musical compositions using a combination of traditional Lampung musical instruments with traditional musical instruments from other regions. In addition, there are also modern musical instruments that are also integrated into their music, namely guitar, bass, saxophone, flute, drum and synthesizer. The combination of the various types of musical instruments is an example of cultural acculturation displayed by this community.

\subsection{Musical Composition by Kulit Tipis} Community

Exploration carried out by the Kulit Tipis community is by bringing various types of songs, ranging from modern pop songs to traditional songs such as dangdut and Lampung folk songs.

In exploring the traditional music of Lampung, the community rearranges the existing songs into a unique and interesting musical composition, thus making it a special attraction for the community and at the same time as an effort to introduce and invite the community and millennial generation to preserve traditional music, especially Lampung traditional music. Therefore, the Kulit tipis community raised Lampung songs with a millennial or modern concept without leaving their local wisdom.

One of the folk songs arranged by the Kulit tipis community is a song entitled Sang Bumi Ruwa Jurai by Syaiful Anwar. The song is one of Lampung's pop songs which is presented into a modern traditional music composition.

The arrangement of the song combines traditional Lampung musical instruments, such as gamolan pekhing, cengeng, and kendang dok- 
dok with other traditional musical instruments from the other provinces such as the accordion and bamboo flute as well as combining them with modern musical instruments including flute and synthesizer. The song Sang Bumi Ruwa Jurai is arranged in such a way as to present enjoyable regional music for the listeners. The following is the notation for the song Sang Bumi Ruwa Jurai:

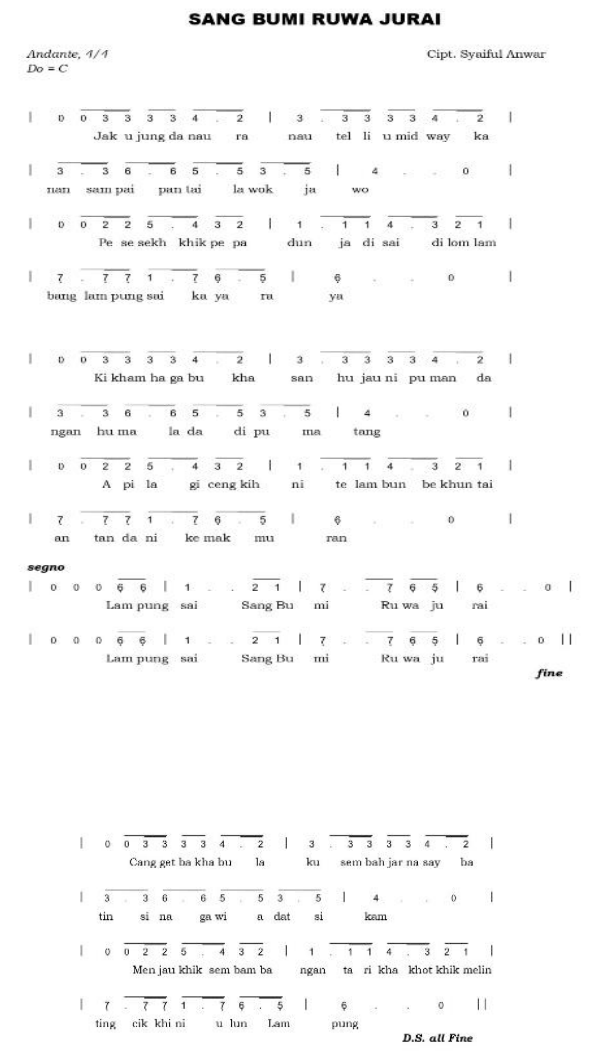

Figure 1. Notation of the Song Sang Bumi Ruwa Jurai.

The figure above showed the original notation of the song Sang Bumi Ruwa Jurai which was created by Syaiful Anwar with the basic tone of C Major and the Sukat used 4/4 with andante tempo.

\subsubsection{Melody}

In the original composition, the song Sang Bumi Ruwa Jurai is played with a scale of $\mathrm{C}=\mathrm{Do}$ with a minor chord progression, while in a composition that has been arranged by the Kulit Tipis community, it is played using a G scale with a minor chord progression in the whole song. Also, there is a modulation to the A scale in the middle of the song. Previously, there was a temporary modulation or bridge, namely $\mathrm{E}$ and $\mathrm{F}$ as interludes in the song. Then arrived at the basic tone modulation A which is back again to the chorus and ended by coda.

The following is the melody of the Sang Bumi Ruwa Jurai song arrangement performed by the Kulit Tipis community:

\subsubsection{Flute Instrument}

This melody is played on bar 1 to bar 49 , namely in stanza 1 , stanza 2 , chorus 1 , stanza 3 , and chorus 2 .

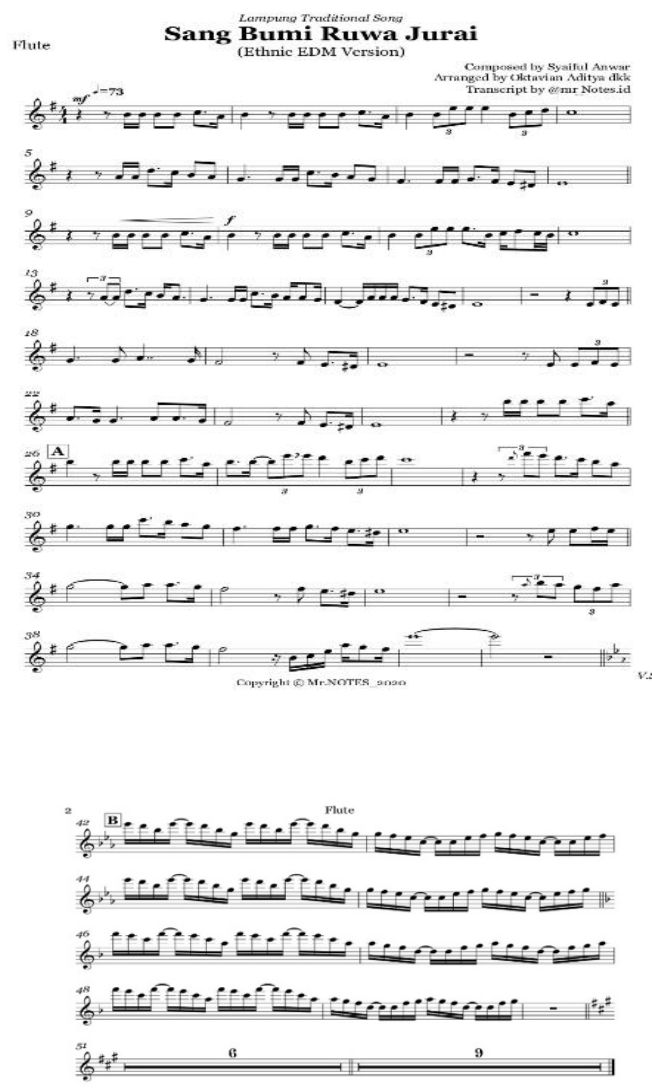


Figure 2. Score Instrument Flute.

Figure 2 is the score for the flute instrument that has been arranged by Okatvian Aditya and has been transcribed and orchestrated.

\subsubsection{Accordion Instrument}

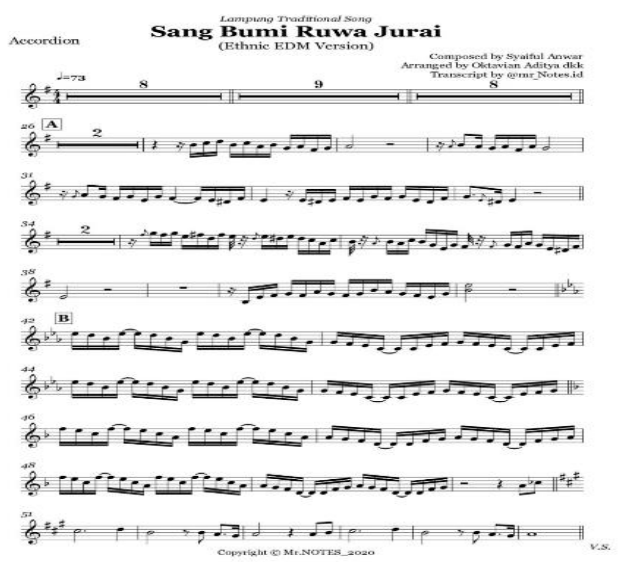

Figure 3. Accordion Instrument Score. (Source: Kulit Tipis Community Private Document)

Figure 3 is the score for the Accordion instrument which has been arranged by Okatvian Aditya and the orchestration transcript by $\mathrm{mr}$ notes.id.

In musical compositions performed by the community, the accordion instrument is used as a melodic variation with the addition of short melodies in places in the song that are considered empty or called filler techniques. Meanwhile, in the interlude, the accordion instrument plays the main melody along with the flute instrument on bars 42 to 49 , followed by two voice melodies at 50 to 56 .

\subsubsection{Bamboo Flute Instrument}

The flute instrument plays the melodies of interlude, chorus 3 and coda on bars 50 to bar 64 (figure 4).

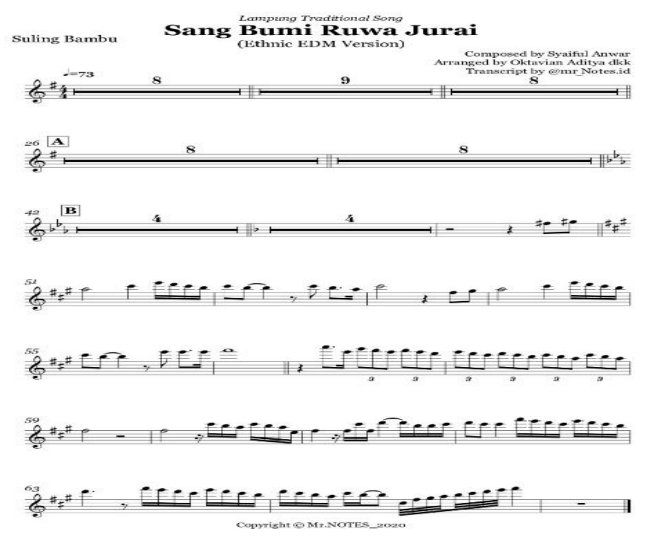

Figure 4. Bamboo Flute Instrument Score.

\subsubsection{Gamolan Pekhing Instrument}

Similar to the accordion instrument, the gamolan pekhing in this composition is also a melody variation in the form of filler and in the form of tone movements taken from the elements of the chord tone being played. The gamolan peking instrument playing is found on bars 18 to 23 , bars 34 to bars 35 , bars 38 to bars 41 , and in the coda section at bars 56 to 64 (figure 5).

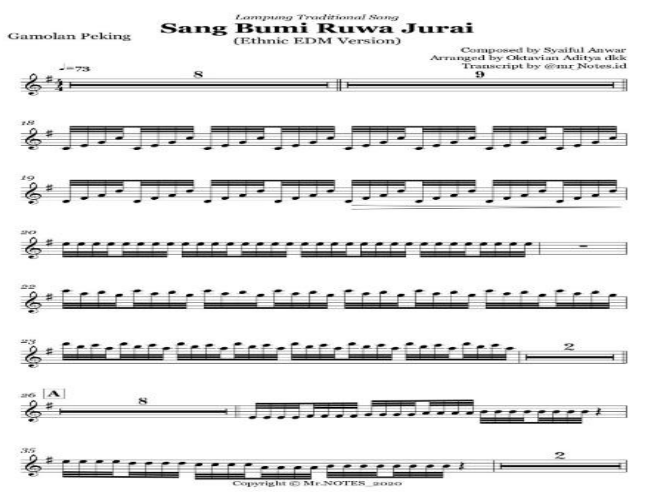




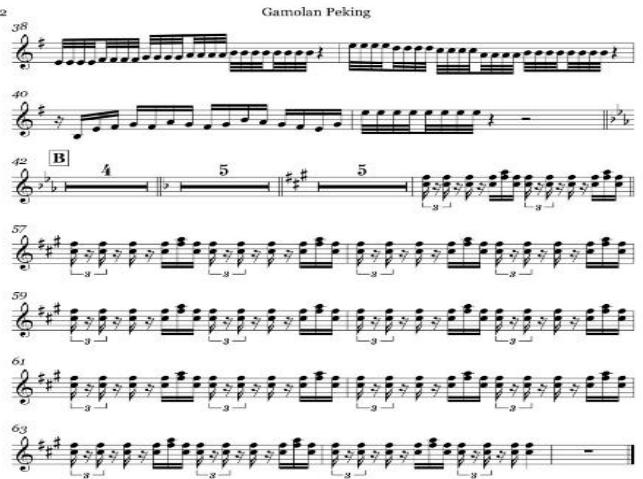

Figure 5. Gamolan Pekhing Instrument Score. Figure 5 is the score for the traditional instrument, namely gamolan pekhing which is written in block notation.

\subsubsection{Rhythm}

In the composition performed by the Kulit Tipis community, the song Sang Bumi Ruwa Jurai has $4 / 4$ bars with a total of 64 bars. In songs with a 4/4 measure, the heavy accent is on the first hint while the second, third and fourth counts have a light accent. The main rhythm that stands out in this musical composition is controlled by the EDM beat on the synthesizer and there is also a drum instrument dok-dok and Kerenceng as rhythmic music in the musical composition.

\subsubsection{Kerenceng Instrument}

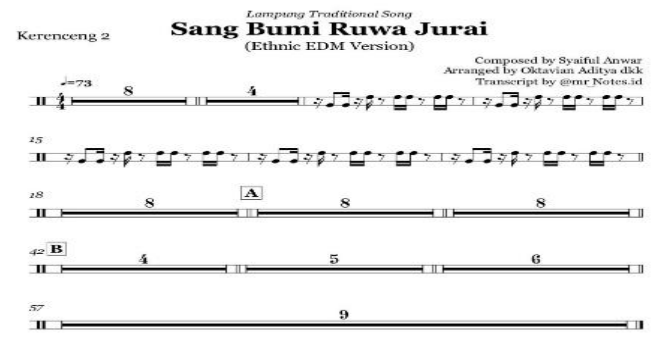

Figure 6. Kerenceng Instrumental Score

In the musical compositions performed by the community, there are two cool instruments that are both played on the 13th to 17th bars with slightly different patterns. On the ring 1 starts on the first beat, while on the ring 2 starts on $1 / 4$ beat.

2.2.2.2 Dok-Dok Drum Instrument
The dok dok drum instrument in this musical composition is played at bars 10 to bars 17 and at the end of the song, at bars 55 to bar 64 (figure 7).

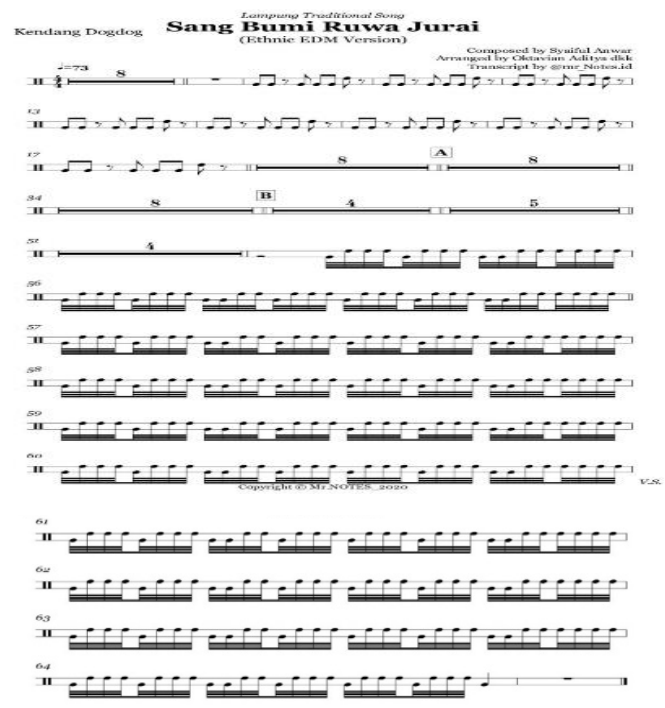

Figure 7. Dok-Dok Drum Instrument Score.

\subsubsection{Instrument Beat EDM Synthesizer}

The rhythmic EDM beat starts at bars 10th to bar 55th and is played back at bars 60th to bar 64th.

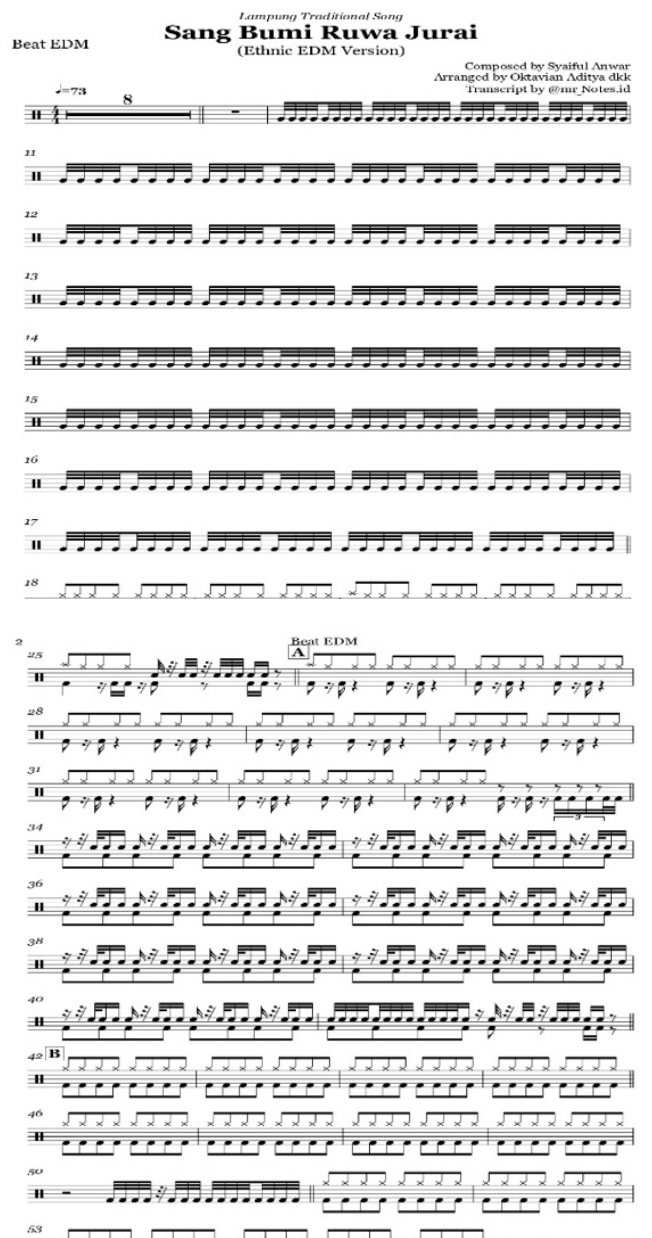




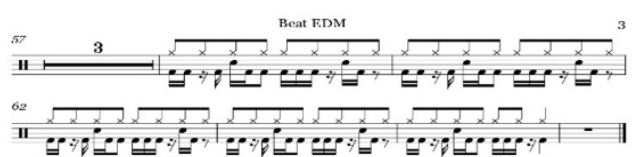

Figure 8. Beat EDM Synthesizer Instrument Score. Figure 8 is a score for a digital instrument, namely the Beat EDM Synthesizer. The following instruments serve as a beat pattern or tempo holder in the song.

\subsubsection{Harmony}

In presenting each musical composition, Kulit Tipis community always pays attention to the elements of music called harmony. This is done so that there is a match between the rhythm and the melody. This is shown in the music game with the collaboration of modern musical instruments with a combination of traditional musical instruments.

Musical harmony instrument in this music composition found in the instrument tape sampler keyboard within synthesizers.
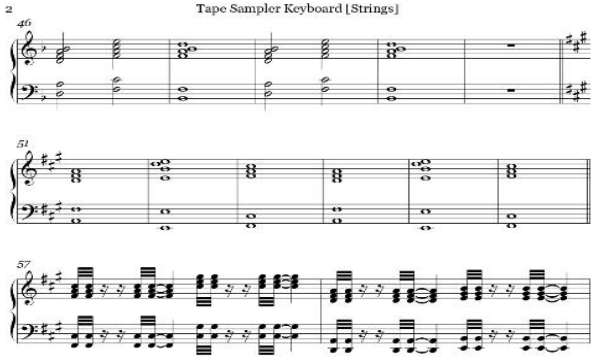

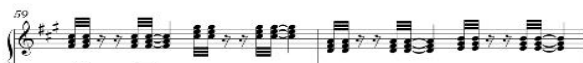

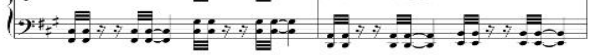

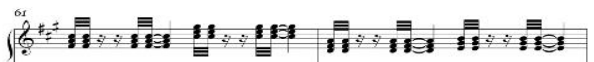
(20,

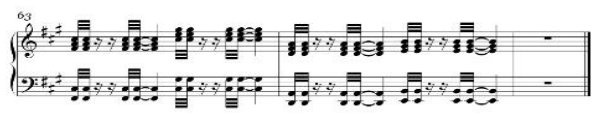
Sang Lumpurs Truataceral Song

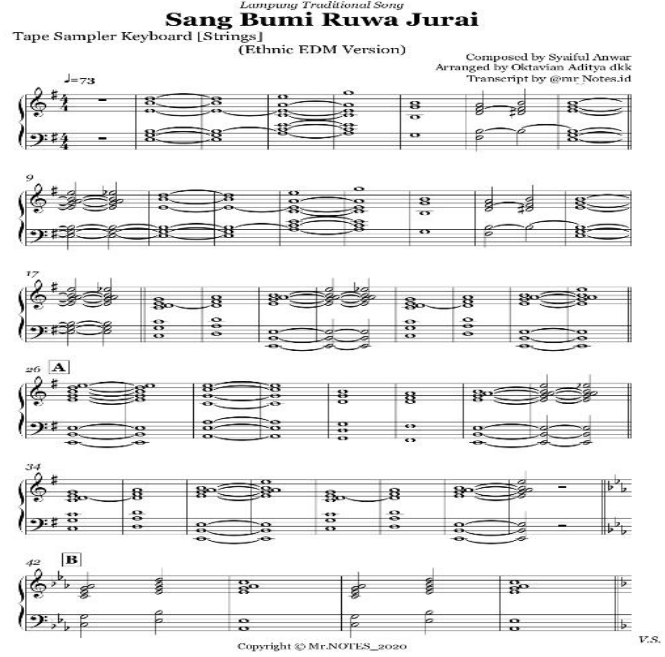

Figure 9. Tape sampler keyboard in synthesizer Instrument Score.

Figure 9 is a musical notation for a digital instrument, namely a tape sampler keyboard in a synthesizer. The instrument serves as a harmony or chord song.

\subsubsection{Tempo, Dynamics, and Expression}

Kulit Tipis community delivers music composition in songs Sang Bumi Ruwa Jurai having tempo andante that stable from the song's beginning until the coda. Besides the tempo, this music composition having dynamics mezzo-forte is produced slightly tinny or a little complex sound. 


\section{The efforts to Preserve Lampung Traditional Music by Kulit Tipis Community in Bandar Lampung}

Entering the modernization era, the Kulit Tipis community in Bandar Lampung makes serious efforts to preserve traditional Lampung music by exploring traditional Lampung music, so Lampung music traditional are not experiencing extinction or substituted by the western culture. Here are the efforts of preserving of traditional music performed by the Kulit Tipis community in Bandar Lampung:

\subsection{Music Performance}

Music performance traditions are direct interaction between the musicians and the audience. In their performance, the Kulit Tipis community not only created music compositions by combining musical instruments but also staged their musicality work to various events. In this way, the community can introduce Lampung traditional music to be recognized in Lampung's community and outside the community.

In every performance, Kulit Tipis community presents traditional music performances with an innovative appearance. Innovative appearance from Kulit Tipis community-supported from several aspects. The first aspect was from the music composition played with various kinds of musical instruments. The second aspect was supported by attractive costumes. Each member of Kulit Tipis community wears the same clothes with a Tanjah Perahu hats, and a Lampung patterned dress with a blend of tapis Lampung cloth. The third aspect was featuring dancers who danced the Lampung traditional dance. It aims to attract the attention and interest of the audience to enjoy their music performances.

\subsection{YouTube Videos by Kulit Tipis Community}

Kulit Tipis community in Bandar Lampung was uploading their video music performances from the work results of composition into a Youtube channel named Kulit Tipis and Vian Harmonic.

\section{CONCLUSION}

Based on the research and discussion results, the writer concludes that the exploration carried out by Kulit Tipis community to maintain and preserve Lampung traditional music so still exists in the current millennial era. The way is by using exploring compositions of melodies, instrumentation, and harmony by producing creative and innovative performances that the audience can enjoy through live shows and internet media.

\section{REFERENCES}

Agustiansyah, A. B. (2017). Srategi Komunikasi Band Underground Karinding Attack Dalam Melestarikan Alat Musik Tradisional Karinding. Jurnal Ilmu Komunikasi, 2(1).

Ali, M. (2006). Seni Musik SMA untuk Kelas X. Jakarta: Erlangga.

Alwasilah, A. C. (2006). Pokoknya Kualitatif. Jakarta: Pustaka Jaya.

Arikunto, S. (2006). Metode Penelitian Kualitatif. Jakarta: Bumi Aksara.

Arikunto, S. (2010). Prosedur Penelitian. Jakarta: PT. Rineka Cipta.

Atthoriq, W. dkk. (2015). Senting Meter. EJurnal Sendratasik FBS Universitas Negeri Padang, 4(1).

Banoe, P. (2003a). Kamus Musik. Yogyakarta: Kanisius.

Banoe, P. (2003b). Kamus Musik. Jakarta: PT. Kanisius.

Bogdan and Biklen. (1992). Qualitative Research for Education: An Introduction to Theory and Method. Boston: Allyn and Bacon, Inc.

Cristine, A. (1972). Haper's Dictionary of Music. London: Barnes and Noble Book a Devision of Harperan row, Stow San Frasisco.

Endarmoko, E. (2006). Tesaurus Bahasa Indonesia. Jakarta: Gramedia Pustaka Utama. 
Esten,

M.

MinangkabauTradisidanPerubahan.

Padang: Angkasa Raya.

Febriyando. (2017). Kolaborasi Musik Rock Dan Alat Musik Polopalo Dalam Karya "The Physical Compate" (Sebuah Eksplorasi Musik). Jurnal Warna, 1(1).

Hadi, Y. S. (2011). Koreografi: Bentuk-TeknikIsi. Yogyakarta: Cipta Media.

Hawkins, P. (2012). Creating a Coaching Culture. New York: Bell and Bain Ltd.

Herawati, E. N. (2012). Eksplorasi Pemanfaatan Seni Tradisional Pada Desa-Desa Wisata Di Kabupaten Sleman. Jurnal Seni Dan Pendidikan Seni, Vol 10(No.1).

Jamalus. (1988a). Panduan Pengajaran Buku Pengajaran Musik melalui Pengalaman Musik. Jakarta: Proyek pengembangan Lembaga Pendidikan.

Jamalus. (1988b). Panduan Pengajaran Buku Pengaran Musik Melalui Pengalaman Musik. Jakarta: Proyek Pengembangan Lembaga Pendidikan.
Joseph, W. (2005). Teori Musik 1. Semarang: Universitas Negeri Semarang.

Kobi, M. F. (2017). Campursari: Bentuk Lain Dari Kesenian Gamelan yang Diterima di Masa Modern. Jurnal Warna, 1(1).

Kodijat, L. (1986). Istilah-Istilah Musik (2nd ed.). Jakarta: Djambatan.

Koentjaraningrat. (2000). Pengantar Ilmu Antropologi. Jakarta: PT. Rineka Cipta.

Kristianto, J. (2007). Gitarpedia. Jakarta: PT. Gramedia Pustaka Utama.

Kusumawati, H. (2004). Komposisi Dasar. Yogyakarta: Universitas Negeri Yogyakarta.

Liliweri, A. (2002). Makna Budaya dalam Komunikasi antar Budaya. Yogyakarta: PT. LKiS Pelangi Aksara. 